\title{
Evaluation of the necessity of whole-body scan tomography in cases with head trauma
}

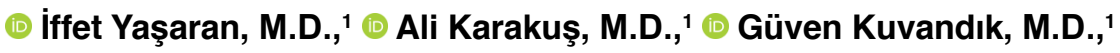 \\ (1) Ahmet Sebe, M.D., ${ }^{2} \odot$ Zeynep Kekeç, M.D. ${ }^{2}$
}

${ }^{1}$ Department of Emergency Medicine, Mustafa Kemal University Faculty of Medicine, Hatay-Turkey

${ }^{2}$ Department of Emergency Medicine, Çukurova University Faculty of Medicine, Adana-Turkey

\begin{abstract}
BACKGROUND: In our study, we have tried to find out how necessary whole-body computed tomography (WBCT) is to detect other body injuries that may accompany the patients, evaluating head trauma cases with WBCT.

METHODS: In our study, we included 198 patients, who were referred to our hospital's emergency service after head trauma, had brain lesions detected in brain tomography (BT), had no additional examination findings and who underwent WBCT. In this retrospective study, patients' age, gender, type of lesion in brain CT, Glasgow Coma Scale (GCS) values and WBCT findings were examined.

RESULTS: In this study, $85.4 \%$ of the patients were male and the average age was 25.7 years. The most common cranial CT findings were fracture, followed by parenchymal bleeding. $67 \%$ of the patients' GCS were below 8 . Additional trauma was detected in 78 of the patients (39.4\%). The most common additional lesion was the thoracic contusion. The mean age of the patients with cervical injuries determined in CT was significantly high $(p<0.05)$. Statistical significance was determined between cranial fracture, foreign body incidence and thoracic injuries $(p<0.05)$. The incidence of cervical injuries was significantly higher in patients with brain contusion detected in CT $(p<0.05)$. Fracture frequency and presence of additional lesions in WBCT were significantly high $(p<0.05)$. There was no correlation between other cranial lesions and additional injury areas $(p>0.05)$.
\end{abstract}

CONCLUSION: The number of studies evaluating WBCT is high in the literature. However, our study is important concerning that to our knowledge this study is the first study to evaluate the WBCT findings in the head trauma cases without the additional lesions on their bodies. WBCT scan should be recommended in patients whose clinical evaluation could not be completed. WBCT is an important diagnostic tool for the diagnosis of many pathologies, especially for intrathoracic lesions.

Keywords: Cranial trauma; emergency department; whole-body CT.

\section{INTRODUCTION}

Trauma is the most important cause of death among young adults all over the world. Early diagnoses of traumas reduce both mortality and morbidity. ${ }^{[1]}$ In addition to the surgery, direct graphs, ultrasonography (USG) and contrasted-non contrast CTs are used to detect damage to the body. WBCT has been an important diagnostic tool, especially in the evaluation of the cases in the last decade. ${ }^{[2-4]}$ Emergency Depart- ments are places where anamnesis and physical examination cannot sometimes be clearly assessed. Patients presented with trauma to the hospital cannot be questioned due to reasons, such as unconsciousness, absence of their relatives, communication problems, and a complete physical examination cannot be carried out. Thus, most physicians are prone to missing the injuries associated with head trauma in the emergency department. This leads to an increased mortality and morbidity of head trauma cases. Hence, in our study, we

Cite this article as: Yaşaran İ, Karakuş A, Kuvandık G, Sebe A, Kekeç Z. Evaluation of the necessity of whole-body scan tomography in cases with head trauma. Ulus Travma Acil Cerrahi Derg 2019;25:622-627.

Address for correspondence: Ali Karakuş, M.D.

Mustafa Kemal Üniversitesi Tıp Fakültesi, Acil Tıp Anabilim Dalı, 31100 Hatay, Turkey

Tel: +90 326 - 2291000 E-mail: drkarakus@yahoo.com

Ulus Travma Acil Cerrahi Derg 2019;25(6):622-627 DOI: 10.14744/tjtes.2019.42675 Submitted: 16.05.2018 Accepted: 05.02.2019 Online: 01.1I.2019 Copyright 2019 Turkish Association of Trauma and Emergency Surgery 
tried to determine the necessity of using WBCT to detect pathologies that may accompany head trauma cases.

\section{MATERIALS AND METHODS}

The present study was carried out retrospectively at the Emergency Medicine Department after being approved by Hatay Mustafa Kemal University Faculty of Medicine ethics committee. This study was conducted in accordance with the latest version of the "Helsinki Declaration" and the "Good Clinical Practice Directive". Patients who applied to the Emergency Department of our hospital between the dates of 2012-2016 with head trauma and who underwent WBCT were included and 2358 trauma patients applied, and 1206 of these patients had head trauma. It was determined that 567 of the patients with head trauma underwent WBCT. One hundred ninety-eight patients were included in this study. $\mathrm{Pa}$ tients diagnosed with lesion or examination findings in other organ systems, patients with organ injuries determined using USG or CT in our hospital or in another medical center, patients with a known bleeding disorder, and patients with additional trauma in their history were excluded from this study.

Patients' age, gender, type of lesion in brain CT, GCS status and WBCT findings were evaluated. The data were analyzed in SPSS Windows version 18. Mean, median, standard deviation and frequency values were used in the descriptive statistics of the data. The distribution of the variables was checked us- ing the Kolmogorov Smirnov Test. Mann-Whitney $U$ test was used for numerical non-parametric data. In the analysis of qualitative data, the Pearson chi-square test and Fisher's chi-square test were used. $P<0.05$ was considered statistically significant.

\section{Patient Selection Criteria}

Nowadays, studies for selecting the WBCT as an indication continue, but the criteria for selecting patients has not been determined. In some trauma centers, patient selection criteria are based on vital parameters, injury mechanisms and clinical suspicion of specific injuries in a three-legged structure. The REACT-2 study is one of them and is a forwardlooking study. The REACT-2 study and the WBCT inclusion criteria are presented in Table I. Our study is a retrospective study. Patients diagnosed with lesion or examination findings in other organ systems, patients with organ injuries determined using USG or CT in our hospital or in another medical center, patients with a known bleeding disorder, and patients with additional trauma in their history were excluded from the study. Another clinical approach scheme for the determination of WBCT as an indication has been developed (Fig. I).

\section{RESULTS}

Of the 198 patients who were included in this study, 169 (85.4\%) were male, and 29 (14.6\%) were female. The mean age was $25.7 \pm I 3.8(I-7 I)$. Linear fractures were the most common cranial lesions in patients (Table 2 ).

Table I. REACT-2 Study inclusion and exclusion criteria ${ }^{[5]}$

Inclusion criteria

The presence of one of the following parameters during the trauma patient's admission to the hospital

- Respiratory rate $\geq 30 / \mathrm{min}$ or $\leq 10 / \mathrm{min}$

- Pulse $\geq 120 / \mathrm{min}$

- Systolic blood pressure $\leq 100 \mathrm{mmHg}$

- Estimated blood loss greater than $\geq 500 \mathrm{ml}$

- Glasgow Coma Score $\leq 13$

- Abnormal pupil reaction or clinical suspicion of the following diagnoses

- At least two long bone fractures

- Flail chest, open chest or multiple rib fractures

- Severe abdominal injury

- Pelvic Fracture

- Unstable vertebral fracture or spinal cord pressure

or patients suffering from one of the following trauma mechanisms

- Fall from higher than 3 meters

- Thrown from the car

- Death in the same vehicle

- Serious injury in the same vehicle

- Stuck chest or abdomen

\section{Exclusion}

- Under 18 years old

- Known pregnancy

- Low-energy blunt trauma

- Stab wound in a single anatomical area

- Patients who were assessed as unstable for computed tomography in their clinical evaluation, patients who had cardiopulmonary resuscitation or patients at a high risk of death 


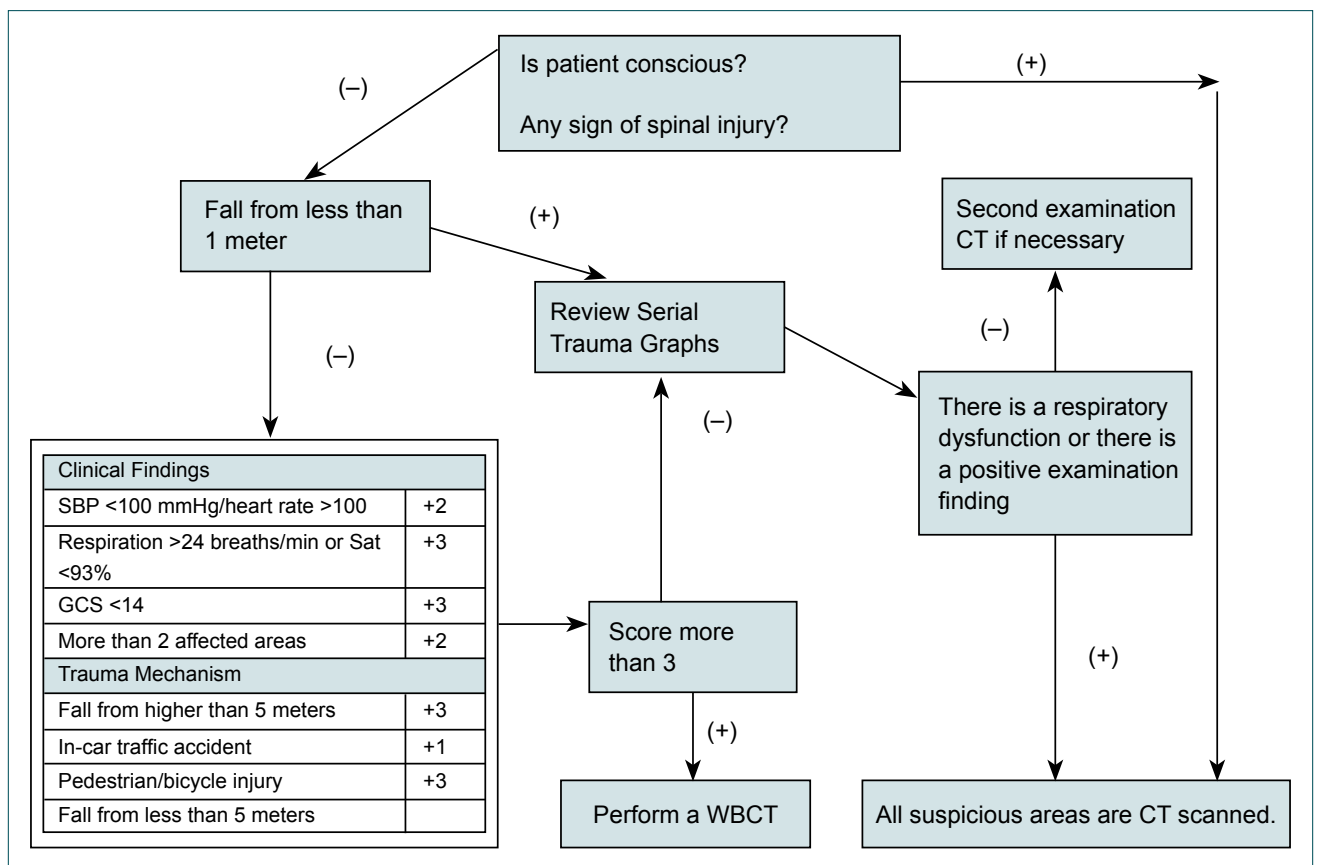

Figure 1. The Manchester Trauma Imaging Protocol. ${ }^{[6]}$

When GCSs of patients are examined; 132 (66.7\%) patients had severe GCS (3-8), 40 (20.2\%) patients had moderate GCS (9-12), and 26 (13.1\%) patients had mild GCS (13-15).

Additional lesions were detected in WBCT in 74 (37.4\%) of the patients. Additional lesions were a thoracic injury in 65 (87.8\%), abdominal injury in 17 (23.0\%), and cervical injury in three $(4.1 \%)$ patients (Table 3 ).

The mean age of patients with cervical injuries was significantly higher $(p<0.05)$.

There was no statistically significant relationship between gender and additional lesions, cervical injury, thoracic injury and abdominal injury $(p>0.05)$.

There was a significant correlation between cranial fracture incidence and patients with thoracic injuries $(p<0.05)$.

Table 2. Cranial lesions of patients

\begin{tabular}{lcc}
\hline Lesion & $\mathbf{n}$ & $\%$ \\
\hline Linear fracture & 175 & 88.4 \\
Intraparenchymal bleeding & 101 & 51 \\
Subarachnoid bleeding (SAB) & 77 & 38.9 \\
Foreign body & 66 & 33.3 \\
Subdural bleeding & 59 & 29.8 \\
Cerebral contusion & 46 & 23.2 \\
Epidural bleeding & 27 & 13.6 \\
\hline
\end{tabular}

There were no significant relationship between parenchymal bleeding and cervical, thoracic and abdominal injuries $(p>0.05)$.

A significant relationship was detected between patients with contusion and patients with cervical injuries ( $p<0.05$-Pearson chi-square test).

There was no significant relationship between $S A B$ and cervical, thoracic and abdominal injuries ( $p>0.05)$.

There were no statistically significant relationship between epidural bleeding and cervical, thoracic and abdominal injuries $(p>0.05)$.

There were no statistically significant relationship between subdural bleeding and cervical, thoracic and abdominal injuries $(p>0.05)$.

Table 3. Additional lesion area and detected pathologies

\begin{tabular}{llll}
\hline Area & Pathology & n & $\%$ \\
\hline Thorax & Contusion & 52 & 80 \\
& Pneumothorax & 6 & 9.2 \\
& Thoracic fracture & 4 & 6.2 \\
& Alveolar hemorrhage & 3 & 4.6 \\
Abdomen & Hemothorax & 1 & 1.5 \\
& Free fluid & 6 & 35.3 \\
& Broken lumber & 6 & 35.3 \\
& Broken pelvis & 5 & 29.4 \\
Cervical & Solid-organ injury & 2 & 11.8 \\
& Fracture & 3 & 100 \\
\hline
\end{tabular}


Table 4. Additional lesion presence in WBCT and comparison of the lesion in cranial CT

\begin{tabular}{lcccccc}
\hline & \multicolumn{2}{c}{$\begin{array}{c}\text { Yes } \\
(\mathbf{n = 7 4 )}\end{array}$} & & \multicolumn{2}{c}{$\begin{array}{c}\text { None } \\
(\mathbf{n}=124)\end{array}$} & $\mathbf{p}$ \\
\cline { 2 - 3 } & $\mathbf{n}$ & $\%$ & & $\mathbf{n}$ & $\%$ & \\
\hline Fracture & 60 & 81.1 & & 115 & 92.7 & 0.013 \\
Parenchymal bleeding & 35 & 47.3 & & 66 & 53.2 & 0.419 \\
Contusion & 19 & 25.7 & & 27 & 21.8 & 0.529 \\
Subarachnoid bleeding & 30 & 40.5 & & 47 & 37.9 & 0.713 \\
Epidural & 10 & 13.5 & & 17 & 13.7 & 0.969 \\
Subdural & 27 & 36.5 & & 32 & 25.8 & 0.112 \\
Foreign body & 20 & 27 & & 46 & 37.1 & 0.146 \\
\hline
\end{tabular}

*Pearson's chi-square test.

Table 5. Comparison of the relationship between GCS score and presence of lesion in WBCT

\begin{tabular}{lcccc}
\hline & $\begin{array}{c}\text { Mild } \\
(\mathbf{n = 2 6 )}\end{array}$ & $\begin{array}{c}\text { Moderate } \\
(\mathbf{n = 4 0 )}\end{array}$ & $\begin{array}{c}\text { Severe } \\
(\mathbf{n}=132)\end{array}$ & $\mathbf{p}$ \\
\hline Yes, n (\%) & $9(34.6)$ & $14(35.0)$ & $51(38.6)$ & 0.873 \\
None, n (\%) & $17(64.4)$ & $26(65.0)$ & $81(61.4)$ & \\
\hline
\end{tabular}

*Pearson's chi-square test. GCS: Glaskow Coma Scale; WBCT: Whole body computed tomography.

There was a significant correlation between the probability of having thoracic trauma and the patients who had intracranial foreign bodies detected on their CT $(p<0.05$-Pearson chisquare test).

Patients with low GCS were found to be exposed to less cervical trauma $(p<0.05)$.

While there was no significant relationship between additional lesions and parenchymal bleeding, contusion, (crush the underlying tissues without breaking the skin with the body of the crushing object) SAB, epidural bleeding, subdural bleeding and presence of foreign body $(p>0.05)$, fracture frequency was significantly high $(p<0.05)($ Table 4$)$.

There was no significant relationship between lesion presence in WBCT and GCS $(p>0.05)$ (Table 5).

\section{DISCUSSION}

Trauma is the first cause of mortality in young and healthy patients. ${ }^{[7-10]}$ In literature review, individuals exposed to head trauma appear to be male under 40 years old. Men are 2-3 times more likely to suffer head trauma than women. ${ }^{[1,12]}$ According to the Major Trauma Outcome Study (MTOS), the average age of trauma is 28.9 years and the majority are male $(71 \%)$. In our study $85.4 \%$ of the patients were male and the average age was 25.7 years. The main reason for the low average age of or study may be that penetrant injuries are frequent in the second decade, there is an ongoing war in the region and there is no age restriction in this study.

Studies have shown that as the age increases in patients with trauma, more lesions are detected in WBCT. In many studies, it has been suggested that comorbid conditions may be responsible for this. ${ }^{[13,14]}$ In our study, no association was found between age and the presence of additional trauma in CT. This may be because our patients are younger. The mean age of the patients with cervical injuries determined in CT was significantly high. We think that this may be due to osteoporosis that occurs in bone structures with increasing age.

When patients' brain CTs are evaluated, it is seen that the most common lesions are in different groups. While most common $C T$ finding was said to be cerebral edema in the study conducted by Çökük et al., in other studies, SAB and fractures were the most common findings. ${ }^{[I 5]}$ On the other hand, in our study, the most common cranial CT findings were the fracture, followed by parenchymal bleeding. The reason for this may be the combination of penetrating and blast effect in cases of firearm injuries.

New approaches, trauma systems, diagnostic and therapeutic guidelines developed over time provide a reduction in mortality risk. ${ }^{[16,17]}$ Part of this approach predicts the use of laboratory and imaging methods. ${ }^{[18]}$ The precision of the CT in the diagnosis of trauma patients is $98 \% .^{[19]}$ Thus, CT is often requested. There is evidence that WBCT scanning detects major injuries that may be missed by selective screening. ${ }^{[20]}$ In a study assessing the effects of WBCT on mortality, the findings showed that patients who underwent WBCT had a lower mortality rate than the patients who had selective tomography. ${ }^{[2]]} \mathrm{CT}$ is considered to be beneficial because it shortens the duration of treatment, identify incidental findings and lower the hospital expenses. ${ }^{[22]}$

Despite the adverse effects of WBCT on patients concerning emergency service, WBCT is widely used because of the detection of additional lesions in patients, shortening of the follow-up time of emergency service, reduction of radiological cost and decrease of malpractice rate. ${ }^{[22]}$ In a typical WBCT, the average radiation dose was measured as equivalent to 760 chest radiographs or over five years of natural background radiation acquisition. ${ }^{[23]} \mathrm{It}$ is suggested that the WBCT should be requested as an emergency necessity after a clinical examination of the emergency room physician. ${ }^{[24]}$ Smith et al. ${ }^{[25]}$ evaluated 400 patients with trauma to emergency room physicians and they detected that while physicians are sensitive about serious injuries, they miss many pathologies in simple traumas and were inadequate in detecting mortal pathologies in patients considered as simple trauma. 
In many studies, it has been shown that the percentage of pathology detected in WBCT is more than $50 \%$, but only some of them require intervention. ${ }^{[26]}$ Kroczek et al., ${ }^{[27]}$ in their study of 2440 multi-trauma patients, stated that in $8.4 \%$ of patients who underwent whole-body $\mathrm{CT}$, the lesion requiring urgent intervention was detected, while in $31 \%$ of those who underwent WBCT additional lesions were detected. In our study, additional trauma was detected in 78 patients (39.4\%). We believe that the reason for this is could be that while blast-induced injuries cause mild external lesions, they cause serious damage to internal organs. It may also be due to anamnesis and inadequate physical examination.

There are differences between the most common additional pathological areas and their rates in WBCT of patients with head trauma. The incidence of the trauma of other systems ranges from 15 to $44 \% .{ }^{[28,29]}$ In many studies, it has been stated that in patients who underwent WBCT, the most common finding was in the abdominal and thoracic areas, and the least common lesion was in the cervical area. ${ }^{[1,24,27]}$ In their study of 443 patients, Sabzghabaei et al. ${ }^{[30]}$ found that the incidence of thoracic trauma detected in WBCT was significantly higher compared to selective CT. In our study, the most common additional lesion was thoracic. The reason for this may be because mild and moderate pulmonary contusions are not detected with an examination in cases with head trauma, and even mild traumas lead to contusion.

To our knowledge, there are not any studies in the literature evaluating head trauma subtype and WBCT findings. In our study, there were significant results between cranial fracture, foreign body frequency and thoracic injuries. In our study, the incidence of cervical injury was significantly higher in patients who had contusion in CT. There was no correlation between other cranial lesions and additional injury area.

\section{Conclusion}

The number of studies evaluating WBCT is high in the literature. However, our study is important because to our knowledge this study is the first study to evaluate the WBCT findings in the head trauma cases without the additional lesions on the body. WBCT scan should be recommended in patients whose clinical evaluation could not be completed. WBCT is an important diagnostic tool for the diagnosis of many pathologies, especially for intrathoracic lesions.

\section{Conflict of interest: None declared.}

\section{REFERENCES}

1. Stengel D, Ottersbach C, Kahl T, Nikulka C, Guthoff C, Hartel T, et al. Dose reduction in whole-body computed tomography of multiple injuries (DoReMI): protocol for a prospective cohort study. Scand J Trauma Resusc Emerg Med 2014;22:15.[CrossRef]

2. Kanz KG, Korner M, Linsenmaier U, Kay MV, Huber-Wagner SM, Kreimeier U, et al. [Priority-oriented shock trauma room management with the integration of multiple-view spiral computed tomography]. Unfallchirurg 2004;107:937-44. [CrossRef]

3. Salim A, Sangthong B, Martin M, Brown C, Plurad D, Demetriades D. Whole body imaging in blunt multisystem trauma patients without obvious signs of injury: results of a prospective study. Arc surg 2006;141:46873. [CrossRef]

4. Vyrostek SB, Annest JL, Ryan GW. Surveillance for fatal and nonfatal injuries-United States, 2001. MMWR Surveill Summ 2004;53:1-57.

5. Sierink JC, Treskes K, Edwards MJ, Beuker BJ, den Hartog D, Hohmann $\mathrm{J}$, et al. Immediate total-body CT scanning versus conventional imaging and selective CT scanning in patients with severe trauma (REACT-2): a randomised controlled trial. Lancet 2016;388:673-83. [CrossRef]

6. Sixta S, Moore FO, Ditillo MF, Fox AD, Garcia AJ, Holena D, et al. Screening for thoracolumbar spinal injuries in blunttrauma: an Eastern Association for theSurgery of Trauma practice management guideline. J Trauma Acute Care Surg 2012;73:326-32. [CrossRef]

7. Karakuş A, Kekeç Z, Akçan R, Seydaoğlu G. The relationship of trauma severity and mortality with cardiac enzymes and cytokines at multiple trauma patients. Ulus Travma Acil Cerrahi Derg 2012;18:289-95. [CrossRef]

8. Karakuș A, Yengil E, Akkücük S, Cevik C, Zeren C, Uruc V. The reflection of the Syrian civil war on the emergency department and assessment of hospital costs. Ulus Travma Acil Cerrahi Derg 2013;19:429-33.

9. Inci M, Karakuş A, Rifaioglu MM, Yengil E, Atçi N, Akin Ö, et al. A practice report of bladder injuries due to gunshot wounds in Syrian refugees. Ulus Travma Acil Cerrahi Derg 2014;20:371-5. [CrossRef]

10. Wade CE, del Junco DJ, Holcomb JB; Trauma Outcomes Group, Holcomb JB, Wade CE, et al. Variations between level I trauma centers in 24-hour mortality in severely injured patients requiring a massive transfusion. J Trauma 2011;71:S389-93. [CrossRef]

11. Çökük A, Kozacı N, Ay MO, Açıkalın A, Seviner M, Satar S. Acil Servise Başvuran Kafa Travması Olgularının Değerlendirilmesi. Cukurova Medical Journal 2013;38:63-71.

12. Vernberg D, Nedd K. Epidemiology of brain injury. In: Greenberg J, editor. Handbook of Head and Spine Trauma. New York: Marcel Dekker Inc; 1993.

13. Woischneck D, Peters B, Kapapa T, Skalei M, Firsching R. [Comparison of younger and elder patients after multiple trauma]. Versicherungsmedizin 2013;65:4-8.

14. Giannoudis PV, Harwood PJ, Court-Brown C, Pape HC. Severe and multiple trauma in older patients; incidence and mortality. Injury 2009;40:362-7.[CrossRef]

15. Rosi Junior J, Figueiredo EG, Rocha EP, Andrade AF, Rasslan S, Teixeira MJ. Whole-body computerized tomography and concomitant spine and head injuries: a study of 355 cases. Neurosurg Rev 2012;35:437-44.

16. MacKenzie EJ, Rivara FP, Jurkovich GJ, Nathens AB, Frey KP, Egleston $\mathrm{BL}$, et al. A national evaluation of the effect of trauma-center care on mortality. N Engl J Med 2006;354:366-78. [CrossRef]

17. Cudnik MT, Newgard CD, Sayre MR, Steinberg SM. Level I versus Level II trauma centers: an outcomes-based assessment. J Trauma 2009;66:1321-6. [CrossRef]

18. Snyder GE. Whole-body imaging in blunt multisystem trauma patients who were never examined. Mosby 2008;52:101-3. [CrossRef]

19. Çevik AA. Majör Travma Hastalarında Tüm Vücut BT Gerekli mi?. Available at: https://www.acilci.net/major-travma-hastalarinda-tum-vucut-bt-gerekli-mi/. Accessed Apr 05, 2017.

20. Walsh L, Shore R, Auvinen A, Jung T, Wakeford R. Risks from CT scanswhat do recent studies tell us? J Radiol Prot 2014;34:E1-5. [CrossRef]

21. Caputo ND, Stahmer C, Lim G, Shah K. Whole-body computed tomographic scanning leads to better survival as opposed to selective scanning 
in trauma patients: a systematic review and meta-analysis. J Trauma Acute Care Surg 2014;77:534-9. [CrossRef]

22. James MK, Schubl SD, Francois MP, Doughlin GK, Lee SW. Introduction of a pan-scan protocol for blunt trauma activations: what are the consequences? Am J Emerg Med 2017;35:13-9. [CrossRef]

23. The Royal College of Radiologists. iRefer: Making the best use of clinical radiology. London: The Royal College of Radiologists; 2012.

24. Shannon L, Peachey T, Skipper N, Adiotomre E, Chopra A, Marappan $\mathrm{B}$, et al. Comparison of clinically suspected injuries with injuries detected at whole-body CT in suspected multi-trauma victims. Clin Radiol 2015;7:1205-11. [CrossRef]

25. Smith CB, Barrett TW, Berger CL, Zhou C, Thurman RJ, Wrenn KD. Prediction of blunt traumatic injury in high-acuity patients: bedside examination vs computed tomography. Am J Emerg Med 2011;29:1-10.

26. Seah MK, Murphy CG, McDonald S, Carrothers A. Incidental findings on whole-body trauma computed tomography: Experience at a major trauma centre. Injury 2016;47:691-4. [CrossRef]

27. Kroczek EK, Wieners G, Steffen I, Lindner T, Streitparth F, Hamm B, et al. Non-traumatic incidental findings in patients undergoing wholebody computed tomography at initial emergency admission. Emerg Med J 2017;34:643-646. [CrossRef]

28. Karasu A, Sabancı PA, Cansever T, Hepgül KT, İmer M, Dolaș İ, et al. [Epidemiological study in head injury patients]. [Article in Turkish] Ulus Travma Acil Cerrahi Derg 2009;15:159-63.

29. Mirzai H, Yağlı N, Tekin İ. [Epidemiologic and clinical features of cases applying to Celal Bayar University emergency unit with head trauma]. [Article in Turkish] Ulus Travma Derg 2005;11:146-52.

30. Sabzghabaei A, Shojaee M, Kariman H, Manouchehrifar M, Heydari K, Sohrabi S. Pan vs. Selective Computed Tomography Scans in Management of Multiple Trauma Patients; a Brief Report. Emerg 2017;5:e38.

\section{ORİINAL ÇALIŞMA - ÖZET}

\section{Kafa travmalı olgularda tüm vücut tarama tomografisinin gerekliliğinin değerlendirilmesi Dr. İffet Yaşaran, ${ }^{1}$ Dr. Ali Karakuş, ${ }^{1}$ Dr. Güven Kuvandık, ${ }^{1}$ Dr. Ahmet Sebe, ${ }^{2}$ Dr. Zeynep Kekeç ${ }^{2}$}

${ }^{1}$ Mustafa Kemal Üniversitesi Tıp Fakültesi, Acil Tıp Anabilim Dalı, Hatay

${ }^{2}$ Çukurova Üniversitesi Tıp Fakültesi, Acil Tıp Anabilim Dalı, Adana

AMAÇ: Bu çalışmada, kafa travmalı olguların tüm vücut bilgisayarlı tomografi (TVBT) ile değerlendirilip, hastalarda eşlik edebilecek diğer vücut yaralanmalarının tespiti için TVBT'nin ne kadar gerekli olduğu ortaya konmaya çalışıldı.

GEREÇ VE YÖNTEM: Çalışmamıza 2012-2016 tarihleri arasında hastanemiz acil servisine kafa travması sonrasında başvurmuş, beyin tomografisinde (BT) lezyon saptanmış, ek muayene bulgusu olmayan ve TVBT çekilmiş 198 hasta alındı. Geriye dönük olarak yapılan çalışmada hastaların yaş, cinsiyet, beyin BT'deki lezyonun tipi, Glaskow Koma Skalası (GKS) değerleri ve TVBT bulguları incelendi.

BULGULAR: Hastaların \%85.4'ü erkek olup, yaş ortalaması 25.7 yıldı. En sık saptanan kraniyal BT bulgusu kırık, takiben parankimal kanamaydı. Hastaların \%67'sinin GKS'si 8'in altındaydı. Hastaların 78'inde (\%39.4) ek travma saptandı. En sık saptanan ek lezyon toraksta kontüzyondu. BT'de belirlenen servikal yaralanması olan hastaların yaş ortancaları anlamlı olarak yüksekti $(p<0.05)$. Kraniyal kırık ve yabancı cisim sıklığı ile toraks yaralanması arasında anlamlılık tespit edildi $(p<0.05)$. Beyin BT'de kontüzyon saptanan hastalarda servikal yaralanma sıklığı anlamlı olarak yüksekti $(p<0.05)$. TVBT'de ek lezyon varlığı ile kırık sıklığı anlamlı olarak yüksekti $(p<0.05)$. Diğer kraniyal lezyonlar ve ek yaralanma bölgesi arasında ilişki saptanmadı $(p>0.05)$

TARTIŞMA: Literatürde TVBT'lerin değerlendirildiği çalışma sayısı çoktur. Ancak, çalışmamız kafa travması olan ve vücudunda ek lezyon olmayıp TVBT'deki bulguların değerlendirildiği ilk çalısmadır. Klinik değerlendirilmesi tam yapılamayan hastalarda TVBT çekimi önerilmelidir. TVBT başta toraks içi lezyonlar olmak üzere, birçok patolojinin tanısında önemli bir tanı aracıdır.

Anahtar sözcükler: Acil servis; kraniyal travma; tüm vücut bilgisayarlı tomografi.

Ulus Travma Acil Cerrahi Derg 2019;25(6):622-627 doi: 10.14744/tites.2019.42675 